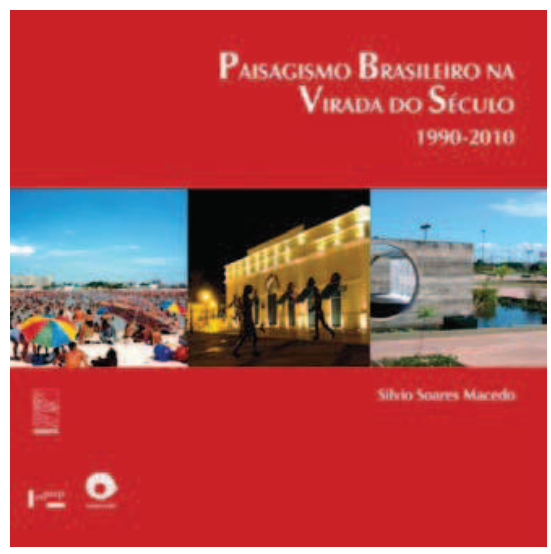

Paisagismo brasileiro

NA VIRADA DO SÉCULO:

I990-20IO

MACEdo, Sílvio Soares: São Paulo: Edusp; Editora da Unicamp, 2012

ISBN: 978-85-3I4-I358-2 (EDUSP) ISBN: 978-85-268-0964-2 (EDITORA DA UNICAMP)

Eugenio Fernandes Queiroga

\title{
UM OLHAR ABRANGENTE SOBRE A PAISAGEM URBANA E O PAISAGISMO BRASILEIRO NA CONTEMPORANEIDADE
}

Em Paisagismo Brasileiro na Virada do Século, Silvio Macedo (2012) apresenta, com profundo conhecimento empírico, um vasto quadro da produção paisagística contemporânea brasileira. O livro é ricamente ilustrado, com muitas imagens em grandes dimensões, que surpreendem o leitor com prazer e conhecimento. Não se trata apenas de belas fotografias, mas mapas e plantas cuidadosamente elaborados pelo LAB-QUAPÁ da FAUUSP (laboratório criado e coordenado por Macedo, desde 1994) e croquis explicativos, quase todos feitos pelo autor, que tem no desenho poderosa ferramenta de explicação e reflexão crítica sobre os processos de produção da paisagem urbana.

Silvio Macedo demonstra que há inúmeras obras de qualidade para além do eixo Rio-São Paulo. São exemplos, os parques lineares de Rio Branco, no Acre, o tratamento de orlas periféricas em Vitória, no Espírito Santo, ou o sistema de parques de Campo Grande, em Mato Grosso do Sul; apenas para citar três casos que ultrapassam, também, a noção de obra isolada. Tal noção, com frequência, é ainda concebida assim por gestores públicos e agentes privados e, também desta forma, é apresentada em inúmeras publicações, estrangeiras ou nacionais, na área de Paisagismo. A noção de sistema, e em particular de sistema de espaços livres, apresentada pelo autor se constitui em importante chave analítica para a compreensão da realidade da paisagem urbana brasileira.

Silvio Macedo propõe outra maneira de ver o campo do Paisagismo. Desde a publicação de seu Quadro do Paisagismo no Brasil, em 1999, Macedo relaciona os processos de urbanização, sobretudo na escala intraurbana, sua constituição formal (a dinâmica da paisagem urbana), com as obras de 
paisagismo em sentido estrito (projetos de espaços livres, sejam eles propriedades públicas ou privadas), não esquecendo ainda de estabelecer paralelos entre a produção nacional e a estrangeira de referência. Tem-se assim um quadro mais amplo e contextualizado da produção paisagística brasileira, agora para o período que denominou "virada do século".

O livro está estruturado em três grandes capítulos. No primeiro, Silvio Macedo apresenta conceitos de natureza geral que contribuem para as análises no campo do Paisagismo, e de natureza específica para o objeto/ tempo tratado nesta obra; o segundo capítulo enfoca a produção dos espaços livres públicos, e o último discorre sobre a produção dos espaços livres privados.

O mérito maior da obra é sua abrangência, não apenas por tratar efetivamente da escala nacional, ainda que as maiores reflexões do autor recaiam sobre a produção paulista e carioca (sem dúvida, as mais amplas e difundidas no país), mas também porque:

- analisa os principais processos de produção da paisagem urbana (na escala dos tecidos urbanos) das metrópoles e capitais do país. É esta análise que permite a compreensão das formas, funções, sistemas, tipos e desempenho dos espaços livres contemporâneos;

- classifica as linhas projetuais contemporâneas, que vão de atitudes neomodernas a neoecléticas, reconhecendo, sem preconceitos, qualidades em qualquer delas. O que vale é o bom projeto, e isto não se resume a seguir a "tradição" modernista brasileira em Paisagismo;

- não reduz a discussão do Paisagismo à produção mais erudita, apresenta as lógicas culturais, políticas e microeconômicas do que poderia ser chamado de "paisagismo vernacular brasileiro";

- reflete criticamente sobre o processo de produção paisagística de maneira ampla, não se restringe à análise do projeto de paisagismo, mas aos condicionantes mais característicos no âmbito da gestão (geralmente fragmentada), manutenção (quase sempre pior nas áreas periféricas), uso dos espaços livres (novas ideologias e hábitos) e alterações feitas a partir de demandas dos usuários (com frequência, pouco sensíveis à cultura paisagística erudita);

- inclui a dimensão do cotidiano. Interessa mais a Silvio Macedo o que é comum, geral, banal, do que as obras de exceção, sem desmerecê-las, evidentemente. Apoiado na valorização do cotidiano, estabelece, por exemplo, forte crítica aos espaços livres dos conjuntos habitacionais, aos pressupostos do modernismo que deram (ou iludiram) a tantos arquitetos modernos um saber "acima" do povo, de suas culturas regionais. A crítica ao moderno não é de hoje, mas a produção estatal de habitações de interesse social no País continua, em grande parte, cega e surda às heterotopias.

Bem verdade que Macedo não se ocupa das já sedimentadas críticas sociais sobre a produção do espaço urbano em nossa formação socioeconômica. Tal crítica contribui para a compreensão dos processos e dos produtos sócio-espaciais, mas é necessário reconhecer que raramente os trabalhos mais "sociologizantes" na área de Arquitetura vão fundo nas questões 
formais e de paisagem. Há que se construir pontes mais sólidas entre os que discutem processos e os que discutem formas. Ao tratar dos processos de produção da paisagem urbana e seus produtos de ordem paisagística, Silvio Macedo se distancia das leituras meramente formalistas.

Paisagismo Brasileiro na Virada do Século traz à tona a relevância das qualidades formais dos espaços urbanos e a importância do tratamento consequente de seus espaços livres, como questão fundamental para a qualificação das cidades brasileiras. É Macedo, como sempre, aberto ao debate.

\section{Eugenio Fernandes Queiroga}

Arquiteto e urbanista, mestre, doutor e livre-docente pela FAUUUSP. Docente do Departamento de Projeto, orientador na Área de Concentração Paisagem e Ambiente do Programa de Pós-Graduação da FAUUSP. Bolsista do CNPq na modalidade Produtividade em Pesquisa.

Faculdade de Arquitetura e Urbanismo - Universidade de São Paulo

Rua do Lago, 876, Cidade Universitária

05508-080 - São Paulo, SP

(11) 3091-4544

queiroga@usp.br 